\title{
Pamuk Bitkisinde Yüzey ve Yüzeyaltı Damla Sulamanın Toprak Sıcaklığı ve Toplam Kuru Madde (Biomass) Miktarına Etkisi
}

\author{
Öner CCETIN* \\ *Dicle Üniversitesi, Ziraat Fakültesi, Tarımsal Yapılar ve Sulama Bölümü, Diyarbakır
}

*Sorumlu yazar e-mail (Corresponding author e-mail): oner_cetin@yahoo.com

Geliș tarihi (Received) : 04.11.2019

Kabul tarihi (Accepted): 03.01.2020

DOI: $10.21657 /$ topraksu.642197

\section{Öz}

Bu araștırma Güneydoğu Anadolu Bölgesi, Diyarbakır ilinde 2016-2017 yıllarında yapılımıștır. Araștırmada, yüzey (YD) ve yüzeyaltı damla (YAD) sulama ile sulanan pamukta farklı sulama suyu miktarlarının bitki kök bölgesi sıcaklık değișimi ile toprak üstü toplam kuru madde (biomass) miktarına etkisi araștııımıștır. Deneme, tesadüf bloklarında bölünmüș parseller deneme desenine göre 3 tekrarlamalı olarak, ana parseller $I_{1}$ :Yüzey damla, $I_{2}$ :Yüzeyaltı damla-30 $\mathrm{cm}$ ve $\mathrm{I}_{3}$ :Yüzeyaltı damla-40 cm; alt parseller ise, FAO-56 Penman-Monteith (FAO-56 PM) yöntemine göre tahmin edilen referans bitki su tüketimine dayalı ve bundan yararlanarak, bitki Kc yaklașımı ile farklı sulama suyu uygulamaları, $\mathrm{K}_{1}: 1.25 x E T c$, $\mathrm{K}_{2}: 1.00 x E T c$ ve $\mathrm{K}_{3}: 0.75 x E T c$ 'den olușmuștur. Sulama aralığı 5 gündür. Lateralin $10 \mathrm{~cm}$ yakınında farklı derinliklerde yapılan sıcaklık ölçümlerinde, YAD sulamada YD sulamaya göre, sulama öncesinde $35 \mathrm{~cm}$ derinlikte $1.47^{\circ} \mathrm{C}, 30 \mathrm{~cm}$ derinlikte $1.53^{\circ} \mathrm{C}, 20 \mathrm{~cm}$ derinlikte $1.25^{\circ} \mathrm{C}$ ve $10 \mathrm{~cm}$ derinlikte ise 0.69 ${ }^{\circ} \mathrm{C}$ daha yüksek olduğu ölçülmüștür. Bu durum, YD sulamada toprağın üst katmanlarının daha fazla ıslatılması nedeniyle buharlașma sonucu ortamın serinlemesine bağlanabilir. Ayrıca, damlatııların 40 cm derinde olması bu derinlik ve daha așağılarda su hareketi olduğu düșünülürse, üst katmanların daha serin bir ortam olduğundan sıcaklık değerlerinin de YAD sulamada daha yüksek olmasına neden olmuștur. Bu durum YAD sulamasında, bitki kök sistemi ile birlikte toprak üstü aksamının da daha iyi geliștiği görülmüștür. En yüksek ortalama kuru madde (biomas) miktarı (8.79 $\mathrm{t} \mathrm{ha}^{-1}$ ) ve lif veriminin (1865 $\mathrm{kg} \mathrm{ha}^{-1}$ ) $40 \mathrm{~cm}$ derinliğe yerleștirilen YAD sulama sisteminde, FAO-56 PM yöntemine göre tahmin edilen bitki su tüketim değerinin 1.25 katının uygulandığı sulama suyu uygulamasından elde edilmiștir.

Anahtar Kelimeler: Kuru madde (biomass), pamuk, toprak sıcaklığı, yüzey damla sulama, yüzeyaltı damla sulama

\section{Effect of Surface and Subsurface Drip Irrigation on Soil Temperature and Total Biomass For Cotton Production}

\begin{abstract}
This study was caaried out to determine the effects of surface drip (SDI) and subsurface drip irrigation (SSDI) and different amount of irrigation water on soil temperature and biomass during 2016 and 2017 years in Diyarbakır Province of Southeast Anatolia Region in Turkey. The experimental design was split plots in ramdomized bloks with three replications. The main plots had SDI and SSDI with sub-plots in different rates of real-time crop evapotranspiration based on FAO-56 Penman-Monteith (FAO-56 PM) as different amount of irrigation water. The treatments: main plots:: I I : SDI, I, SSDI-30 cm, I $:$ SSDI-40 cm; Subplots: $\mathrm{K}_{1}: \mathrm{I}=\mathrm{ETC} \times 1.25, \mathrm{~K}_{2}: \mathrm{I}=\mathrm{ETC} \times 1.0$ ve $\mathrm{K}_{3}$ : I=ETcx0.75. Irrigation interval was 5 days. According to the temperature measurements before irrigation at $10 \mathrm{~cm}$ near of the lateral for different depths, the temperature was higher $1.47,1.53,1.25$ and $0.69^{\circ} \mathrm{C}$ at $35 \mathrm{~cm}, 30 \mathrm{~cm}, 20 \mathrm{~cm}$ and $10 \mathrm{~cm}$ of depths
\end{abstract}


for the SDI than those for SSDI, respectively. This results attributed that the upper layers of the soil are more wetted by the SDI than SSDI, thus this zone of soil occured more cooler. In adition, considering the depth of $40 \mathrm{~cm}$ for SSDI and moving of some water to the down, upper layer could be cooler compared to the lower layers of soil. Thus, plant root development and biomass was higher under the SSDI conditions. The maximum biomass $\left(8.79 \mathrm{t} \mathrm{ha}^{-1}\right)$ and lint yield (1865 $\left.\mathrm{kg} \mathrm{ha}^{-1}\right)$ was obtained from the treatment in which the SSDI with the depth of $40 \mathrm{~cm}$ and amount of irrigation applied under the the rate of 1.25 of crop evapotranspiration.

Keywords: Cotton, surface drip irrigation, subsurface drip irrigation, soil temperature, biomass

\section{GíRiș}

Pamuk tekstil için ham materyal sağlaması yanında, besin ve yağ sanayisi için de önemli bir bitkidir. Cünkü pamuk tohumlarında yaklașık \% 17 26 yağ ve \% $19-30$ arasında protein bulunmaktadır (Swern, 1982).

Ülkemizde yıllık yaklașık 440000 ha alanda, 2.2 milyon ton kütlü pamuk üretimi gerçekleșmektedir. Ortalama kütlü pamuk verimi ise yaklașı $4510 \mathrm{~kg}$ ha-1'dır. Dünya sıralamasında ise \%4'lük üretim ile 9. sıradadır (Anonim, 2016). Pamuk ülkemizde Ege, Akdeniz ve Güneydoğu Anadolu Bölgelerinde yetiștirilmektedir. Bu bölgelerde iklim ve toprak özellikleri büyük farklılık gösterdiğinden, yetiștirilen pamuk sulama suyu intiyacı dolayısıyla pamuk sulama programları da bölgelere göre farklılık göstermektedir. Güneydoğu Anadolu Projesi'nin (GAP) etkisiyle büyük alanların sulamaya açılması, iklim ve toprak koșullarının da uygun olması nedeniyle Güneydoğu Anadolu Bölgesi ülke pamuk üretiminin \%50'den fazlasını üretmektedir (Çetin ve Üzen, 2016).

Pamuk, sulanan diğer bitkilerle kıyaslandığında oldukça yüksek bitki su tüketimi nedeniyle fazla sulama suyu intiyacı olan bir bitkidir. Buna bağlı olarak iyi bir pamuk yetiștiriciliğinde, farklı sulama yöntemlerine göre pamuk sulama programlarının etkili bir șekilde uygulanması için bitki su tüketiminin karșılanması son derece önemlidir.

Ülkemizin farklı bölgelerinde yapılan araștırmalarda damla sulama karık sulamaya göre yaklașık \%30-40 arasında bir su tasarrufu sağlayabilmektedir. Ayrıca verim ve kalitede önemli artıșlar sağlanmaktadır. Örneğin, Șanlıurfa ilinde pamuk bitkisinde yapılan araștırmaya göre, damla sulama karık sulamaya göre yaklașık \%3043, yağmurlamaya göre ise \%7-18 arasında sulama suyu tasarrufu sağlamıștır (Çetin, 1993). Bu sonuçlara göre pamukta damla sulama kullanılması durumunda maksimum verim için
600-700 mm (6000-7000 $\left.\mathrm{m}^{3} \mathrm{ha}^{-1}\right)$ sulama suyu yeterli olmaktadır. Sulama aralığı ise 5-7 gün arasında değișebilmektedir.

Damla sulama, yüzey damla (YD) ve yüzeyaltı damla (YAD) olmak üzere iki farklı șekilde uygulanabilmektedir. Yüzey altı damla sulamada lateraller toprak altına gömülü olduğu için, toprak yüzeyinden buharlașma kayıpları yok denecek kadar azdır.

Toprak sıcaklığındaki değișimler bitki kök morfolojisinin bir fonksiyonu olarak, kök uzunluğunu, kuru madde miktarını ve kök dallanmasını doğrudan etkiler. Genellikle sıcakık artıșı, bitkinin optimum sıcaklık düzeyine kadar bitki kök gelișimini de artırır. Ayrıca, toprak sıcaklığı, bitki besin elementlerinin köklerce alımı ve besinlerin transformasyonu için en önemli regülatördür (Glinski ve Lipiec, 1990).

Öte yandan, toprak sıcaklığı, bitki kök gelișimi, bitkiden olan transpirasyonu doğrudan etkileyen önemli bir faktördür. Özellikle kurak ve sıcak bölgelerde, akșam üzeri serin havalarda yapılan sulamaların toprak yüzeyini serinleterek toprak yüzey sıcaklığını düșürdüğünü, böylece bitki gelișimi ve verimde olumlu yönde artıșlar olduğu bildirilmiștir. Damla sulamada, gündüz sulamasında gece sulamasına göre, $10 \mathrm{~cm}$ toprak derinliğindeki toprak sıcaklığı daha düșük olmuștur. Bu durum toprak nem içeriği ile ilgilidir. Buna göre mısır bitkisinde, bitki boyunda \% 2, verimde \% 10 artıs meydana gelmiștir (Dong vd., 2016).

Karık ve yağmurlama sulama gibi her seferinde fazla miktarlarda sulama suyu uygulamalarında, toprak yüzeyi serinleyeceği için bitki tranpirasyonu düșer (Ali vd., 1996). Verim ve transpirasyon birbiri ile pozitif ilișkili olduğundan, bu durum verimde azalmalara neden olur. Ayrıca, bitki örtüsünün (kanopisinin) tam toprak yüzeyini örtmediği durumda, toprak ve bitki kanopisi 
arasındaki enerji dengesinde toprak esas etkiye sahiptir. Gündüz, yüzey damlada toprak ISı akısı yüzeyaltı damla sulamaya göre daha fazladır. Bu muhtemelen damlatıcılardan toprak yüzeyine çıkan suyun toprak yüzeyi ve suyun daha yüksek sıcaklığa sahip olmasıyla, yüzey damlada ISI konveksiyonu meydana gelir. Böylece topraktan olan buharlașma için uygun enerji, YD'da daha düșüktür (Dehghanisanij ve Kosari, 2011). Ancak, $15 \mathrm{~cm}$ 'den daha derinde olan YAD sulamalarda gün içinde farklı zamanlarda yapılan sulamaların sulama etkinliği açısından pek farkı olmamıștır (Adams ve Zeleke, 2016).

Öte yandan, bitki toprak üstü toplam kuru madde (biomass) miktarı ile bitki su tüketimi ve sulama suyu arasında önemli pozitif ilișkiler vardır. Pamukta yapraklarda ve gövdede kuru madde (biomass) birikimi, ekimden yaklașık 2 ay sonrası artarken, üreme organlarında ise yaklașık 85 gün sonra artmaktadır (Chen vd., 2017).

Bu araștırmada, Güneydoğu Anadolu Bölgesi Diyarbakır ilinde, 2016-2017 yıllarında, pamukta farklı damla sulama sistemlerinde farklı sulama suyu uygulamalarının toprak sıcaklığı ile toplam kuru madde verimine etkisi incelenmiștir

\section{MATERYAL VE YÖNTEM}

\section{Deneme yeri özellikleri}

Deneme yeri toprakları, düz ve düze yakın eğimli, ABC profilli zonal toprak grubuna girmektedir. Topraklar, tuzluluk ve drenaj sorunu olmayan, potasyum ve kireç yönünden zengin, hafif alkali, fosfor ve organik madde içeriği ise düșüktür. Kil içeriği oldukça yüksek (\%65) kil bünye sınıfına girmektedir.

Denemenin yürütüldüğü Diyarbakır ilinde, yazları sıcak ve kurak, kıșları ise ılık ve yağıșlı bir iklim hâkimdir. Yıllık ortalama yağıș miktarı 491 mm olup, bunun genellikle büyük bir kısmı kıș aylarında ve erken ilkbaharda meydana gelmektedir. Yıllık ortalama minimum, ortalama maksimum ve ortalama sıcaklıklar sırasıyla 8.8, 22.5 ve $15.8^{\circ} \mathrm{C}$ dir.

Uzun yillar meteorolojik verilere göre ilk donlar, Ekim ayı sonunda, son donlar ise Nisan ayı sonunda görülmektedir. Ortalama nispi nem \% 54 olup, aylık nispi nem ortalamaları Temmuz ve Ağustos aylarında \% 20'lere kadar düșmekte olup, Aralık ve Ocak aylarında ise \% 77 civarında olmaktadır.

\section{Denemede kullanılan sulama sistemi ve sulama suyu özellikleri}

Denemede YD ve YAD sulama sistemi kullanılmıștır. YD ve YAD sulamada lateral aralığı her iki pamuk bitki sırasını sulayacak șekilde, lateral aralığı $1.40 \mathrm{~m}$ olarak uygulanmıștır. Damlatıc lateral borular $\varnothing 16$ PE olup, toprak bünyesi ve infiltrasyon hızı esas alınarak damlatıcı aralığı $40 \mathrm{~cm}$, damlatıcı debisi ise $2.2 \mathrm{~L} \mathrm{~h}^{-1}$ seçilip uygulanmıștır. Damla sulama sistemlerinin çalıștırılmasında enerji kaynağı olarak Güneș Enerjisinden (Fotovoltaik Güneș Panelleri) üretilen elektrik enerjisi kullanımıștır. Sulama suyu $\mathrm{pH}^{\prime}$ 's 8.0 , elektriksel iletkenliği ise 0.62 ds $\mathrm{m}^{-1}$ olup, sulama suyu açısından önemli sorunu yoktur.

\section{Deneme yöntemi, konular ve parsel ölçüleri}

Araștırmada Stonville-468 (ST 468) pamuk çeșidi kullanılmıștır (Harem, 2010). Deneme, tesadüf bloklarında bölünmüș parseller deneme desenine göre 3 tekrarlamalı olarak yürütülmüștür. Ana konularda farklı damla sulama sistemleri, alt konularda ise FAO-56 Penamn-Monteith (FAO-56 PM) yöntemine göre tahmin edilen referans bitki su tüketimine dayalı, bitki Kc yaklașımı ile de sulama suyu hesaplanmıș ve kullanılmıștır. Deneme konuları Çizelge 1'de verilmiștir.

Deneme konularına göre parsel alanı: 4.2 × 8.0 m $=33.6 \mathrm{~m}^{2}$ (Toplam 6 sıra ve her 2 sıraya 1 lateral). Bitki sıra aralığı 0.7 m olup, her bir lateral 2 bitki sırasındadır ve böylece lateral aralığı 1.40 m olmuștur.

Çizelge 1. Araștırmada uygulanan deneme konuları

Table 1. Experimental treatments in the study

Ana Konular (Damla sulama sistemleri) Alt Konular (Sulama suyu)

$I_{1}$ : Yüzey damla (YD)

I: Yüzeyaltı damla, (YAD-30 cm)

$\mathrm{I}_{3}$ : Yüzeyaltı damla ((YAD-40 cm)
$K_{1}$ : FAO-56 PM'e göre hesaplanan su tüketiminin (ETC)'nin 1.25 katı sulama suyu olarak uygulamak

$\mathrm{K}_{2}$ : ETc'nin 1.00 katını sulama suyu olarak uygulamak

$K_{3}$ : ETc'nin 0.75 katını sulama suyu olarak uygulamak 


\section{Sulama suyu miktarının hesaplanması}

Sulama suyunun hesabında așağıda verilen Eșitlik (1) ve (2) kullanılmıștır. Seçilen 5 gün sulama aralığındaki gerçek zamanlı FAO-56 PM yöntemine göre tahmin edilen su tüketimi hesaplanmıș ve seçilen sulama konusuna göre uygulama yapılmıștır (Allen vd., 1998).

$E T C=K C \times E T O$

Eșitlikte;

ETc: Tahmin edilen bitki su tüketimi (mm),

Kc: Bitki katsayısı,

ETo: Referans bitki su tüketimi (çim) (mm)'dir.

FAO-56 PM yöntemine göre tahmin edilen bitki su tüketimi (ETc) hesaplandıktan sonra, sulama suyu hesabında ETc'ye bağlı olarak, așağıda verilen Eșitlik 2 kullanılmıștır (Çetin ve Bilgel, 2002).

$I=A \times E T C \times K \times P$

Eșitlikte;

I: Uygulanacak sulama suyu miktarı (L)

A: Sulanacak parsel alanı $\left(\mathrm{m}^{2}\right)$

ETc: Tahmin edilen bitki su tüketimi (FAO-56 PM Yöntemine göre, deneme yeri iklim verileri kullanılmasıyla) (mm).

K: Deneme gereği esas alınan katsayılar veya yüzde oranlar

P: Örtü yüzdesi (\%).

Illk sulamaya bașlandığında örtü yüzdesi \% 35'in altında olduğundan, örtü yüzdesi değeri \% 35 olarak alınmıștır. Örtü yüzdesi değerleri \% 35'i geçtiğinde ise gerçek ölçülen değerler kullanıımıștır (Keller ve Bliesner, 1990).

\section{Toprak sıcaklık ölçümleri}

Toprak sıcaklıkları, toprak yüzeyinden ve toprağın farklı derinliklerinde orta tekerrürdeki YD ve YAD sulama sistemlerinde yapılımıștır. Ölçümler lateralin $10 \mathrm{~cm}$ uzağında 10,20,25, 30 ve $35 \mathrm{~cm}$ derinlikte yapılmıștır. Bu amaçla toprağa batırıabilen seyyar toprak sıcaklık termometresi kullanılmıștır. Ölçümler sulamadan 1 gün önce olmak üzere, saat 10.00'da yapılmıștır. Ölçümler her 15 günde bir, sıcaklık değișimini tespit etmek amacıyla devam etmiștir. YD ve YAD'da sulamanın olası toprak sıcaklığına ve bunun da kuru madde (biomas) üretimine olası etkisi irdelenmiștir (Colaizzi vd., 2004).

\section{Toprak üstü toplam kuru madde (biomass)} miktarının tespit edilmesi

Toprak üstü aksamın toplam kuru madde (biomass) miktarını tespit etmek için bitkinin olgunlașma dönemi (fizyolojik olgunlașma sonunda) her parseli temsil edecek sayıda 110 adet) bitki toprak üstünden kesilip alınarak yaș ağırlık olarak tartılmıștır. Aynı örneklerin yaprak, gövde (dallar) ve tüm bitki organları $0.5 \mathrm{~mm}$ boyutunda öğütülerek $65^{\circ} \mathrm{C}$ kurutulduktan sonra tekrar tartımları alınmıștır (Gardner vd., 1985; Bronson vd., 2003). Her parseldeki toplam bitki sayılarına ve daha sonra da birim alan (ha) bazında toplam kuru madde (biomass) miktarları hesaplanmıștır.

\section{Diğer tarımsal ișlemler}

Denemede kullanılan pamuk tohumları çimlenmeyi kolaylaștırmak için 1 gün önceden suda bekletilerek ıslatılmıștır. Aynı gün akșam saatlerinde tohum ekimi (Stonville-468) yapılmıștır. Ekimler her 2 deneme yılında da, Mayıs ayı bașında yapılmıș olup, hasat ise Ekim ayı bașında gerçekleștirilmiștir.

Gübrelemede, azotlu gübre $130 \mathrm{~kg} \mathrm{~N}$ ha`1, fosforlu gübre $80 \mathrm{~kg} \mathrm{ha-1} \mathrm{P2O5} \mathrm{olarak} \mathrm{eșit}$ dozlar halinde fertigasyonla uygulanmıștır (Özer ve Dağdeviren, 1986; Özer, 1992; Karademir vd., 2005). Fertigasyon her 2 sulamada bir (10 günde bir) uygulanmıștır (Çetin vd., 2013). Azotlu ve fosforlu gübrenin 1/5 oranları ekimle birlikte doğrudan toprağa, kalanı ise fertigasyon yöntemi ile ilk sulama ile bașlayıp, koza olum dönemine kadar devam etmiștir. Buna göre ekimle birlikte toplam uygulanacak net azot intiyacının 1/5'i 20-20-0 ekimle birlikte doğrudan toprağa uygulanmıștır. Kalanı ise deneme konularına göre, 19-5-5-Mikro elementler içeren ticari toz (Compo Basaplant Blue) gübre fertigasyon tekniği ile uygulanmıștır.

\section{BULGULAR VE TARTIȘMA}

\section{Toprak sıcaklığı ölçüm sonuçları}

Deneme yıllarına ait toprak sıcaklık ölçümleri, YD ve laterallerin $40 \mathrm{~cm}$ derinliğe yerleștirilen YAD sulama sisteminde, lateralin $10 \mathrm{~cm}$ uzağında ve farklı derinliklerinde yapılmıștır (Șekil 1 ve 2). Ölçümler belirtilen konumlarda hemen sulama öncesinde yapılmıștır. Buna göre, ölçümler FAO-56 PM yöntemine göre tahmin edilen ETc değerinin tamamının sulama suyu olarak uygulandığı 
(I=1.0xETc) uygulamalarda yapılmıs olup, toprak sıcaklık okuma değerleri tarihleriyle birlikte grafiklenmiștir. Çünkü denemedeki bu uygulama, bitkinin tükettiği kadar sulama suyu uygulamasına dayanmaktadır.
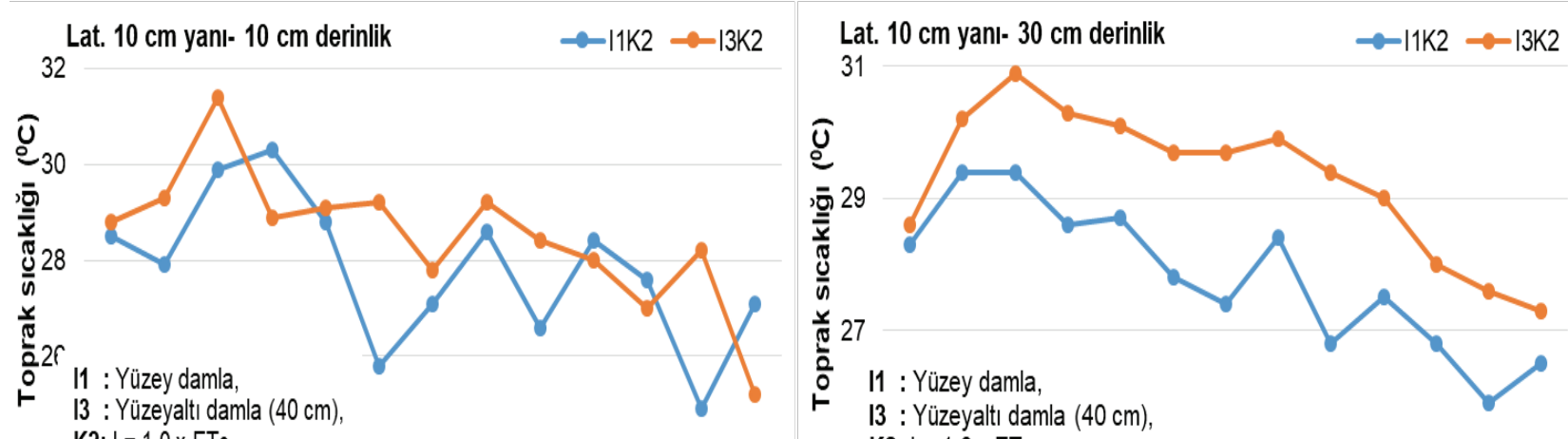

2، K2: $I=1,0 \times E T C$

: Yüzeyaltı damla $(40 \mathrm{~cm})$

$2 \mathrm{~K} 2: \mathrm{I}=1,0 \times \mathrm{ETC}$
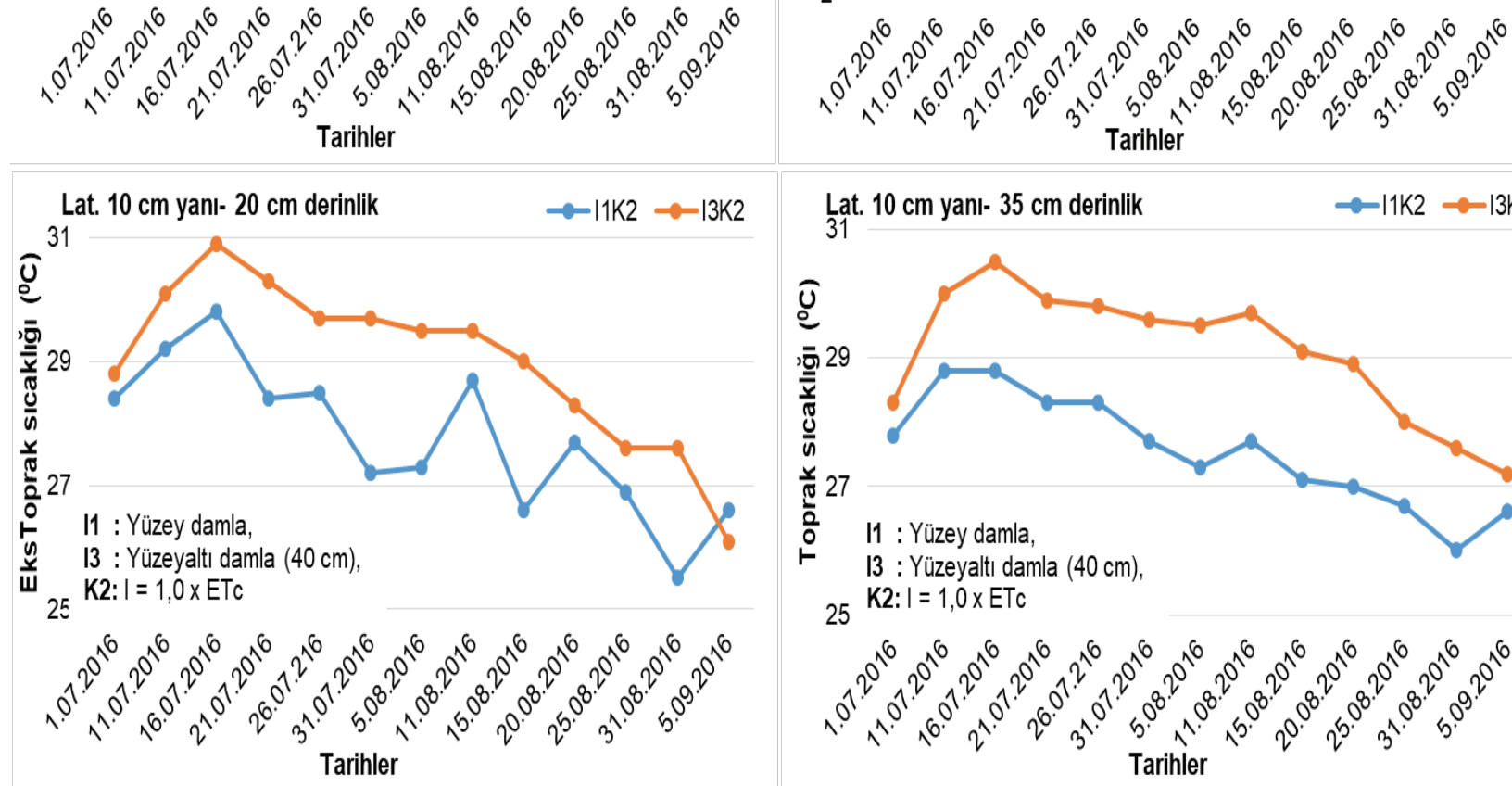

Lat. $10 \mathrm{~cm}$ yanı- $35 \mathrm{~cm}$ derinlik $\quad \rightarrow-11 \mathrm{~K} 2 \multimap-13 \mathrm{~K} 2$

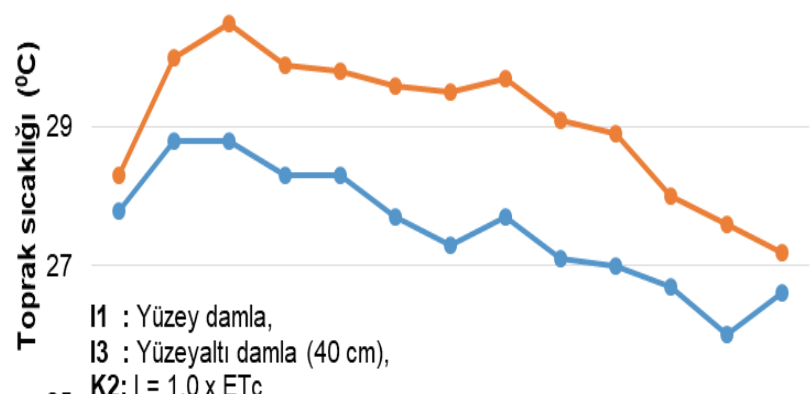

25

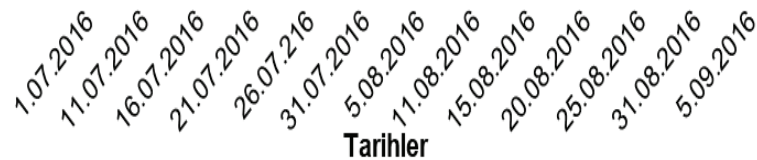

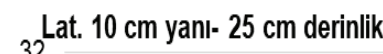 \\ $\rightarrow-11 K 2 \rightarrow-13 K 2$}

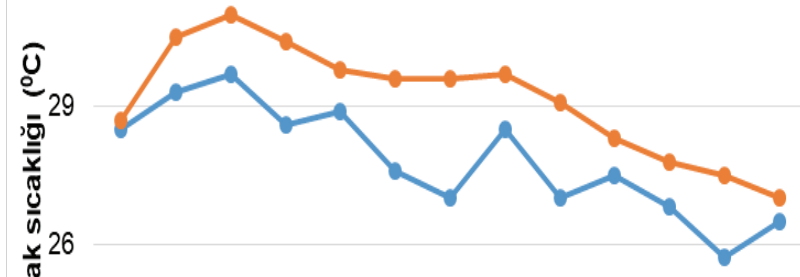

I1: Yüzey damla,

$\stackrel{\circ}{\vdash}$ I3 : Yüzeyaltı damla $(40 \mathrm{~cm})$,

2: $\mathrm{K} 2: \mathrm{I}=1,0 \times \mathrm{ETC}$

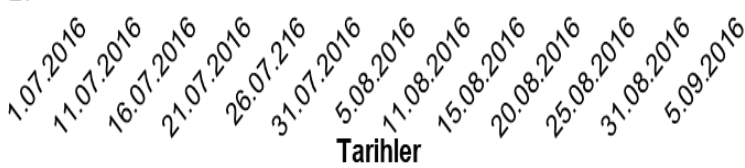

Șekil 1. Yüzey ve yüzeyaltı damla sulama sistemlerinde toprak derinliklerine göre lateralin $10 \mathrm{~cm}$ uzağında toprak sıcaklık değișimi (2016)

Figure 1. Temperature variation near $10 \mathrm{~cm}$ of the lateral under surface and subsurface drip irrigation systems according to different soil depths (2016) 
Lateralin $10 \mathrm{~cm}$ yakınında farklı derinliklerde yapılan sıcaklık ölçümlerinde, YAD'da YD'ya göre, sulama öncesinde $35 \mathrm{~cm}$ derinlikte ortalama 1.47 ${ }^{\circ} \mathrm{C}, 30 \mathrm{~cm}$ derinlikte $1.53{ }^{\circ} \mathrm{C}, 20 \mathrm{~cm}$ derinlikte $1.25^{\circ} \mathrm{C}$ ve $10 \mathrm{~cm}$ derinlikte ise $0.69^{\circ} \mathrm{C}$ daha yüksek olduğu ölçülmüștür (Șekil 1 ve Șekil 2). Bu sonuçlar farklı sulama sistemlerinin, bu araștırmada olduğu gibi, yüzey ve yüzeyaltı damla sulamada toprak sıcaklıklarının farklı olduğunu göstermiștir. Öte yandan, önceden yapılan bir araștırmada ise, toprak katmanının 0-10 cm lik bölümünde farkı sulama uygulamaları ve farklı lokasyonlarda toprak sıcaklıkları arasında farklar olduğu belirtilmiștir. Malc kullanılan parsellerde beklenildiği üzere toprak sıcaklığı daha yüksek ölçülmüștür. Toprak sıcaklık değișiminin toprak düșey yönde malçsız uygulamalarda daha fazla olduğu tespit edilmiștir. Toprak sıcaklığı mısır ekili alan ile çıplak toprakta ve domates yetiștirilen parsellere göre daha yüksek bulunmuștur (Li vd., 2017).

Bitkide transpirasyonun artması verimi artırdığı, azalması ise verimi düșürdüğü belirtilmektedir. YAD sulamada toprak sıcaklığı YD yöntemlerine göre nispi olarak daha yüksek (sıcak) olduğu için verimin de daha yüksek olması beklenir. Yapılan bir araștırmada, Colaizzi vd. (2004), pamukta YAD'da toprak daha sıcak olduğu için diğer LEPA (düșük enerjili hassas sulama) ve yağmurlama sulama sistemlerinin kullanıldığı durumdan daha fazla verim elde etmișlerdir. Böylece daha serin toprak sıcaklığı bitki kök gelișimini azaltmaktadır. Buna göre, bu araștırma sonucu farklı damla sulama sistemlerine göre ölçülen toprak sıcaklıklarındaki farklıık ve özellikle YAD sulamada pamuk lif veriminin neden daha yüksek olduğu gerçeği ile örtüșmektedir. Çünkü pamuk lif verimi YAD sulamada, YD sulamaya göre önemli düzeyde artıș gösterdiği tespit edilmiștir (Șekil 3).

Toprak sıcaklığını sulama yöntemi ile büyük oranda farklılık gösterdiğini, toprak sıcaklığının 0-20 $\mathrm{cm}$ profilde $20-100 \mathrm{~cm}$ profil derinliğine göre daha büyük oranda $\left(3-6^{\circ} \mathrm{C}\right)$ değișim gösterdiği tespit edilmiștir. YD sulamada ise yüzey toprak hariç, toprak sıcaklığının exponental olarak azaldığı tespit edilmiștir (Lv vd., 2013). Öte yandan, mısır bitkisinde YD'da gece sulaması yapıldığında gündüz sulamasına
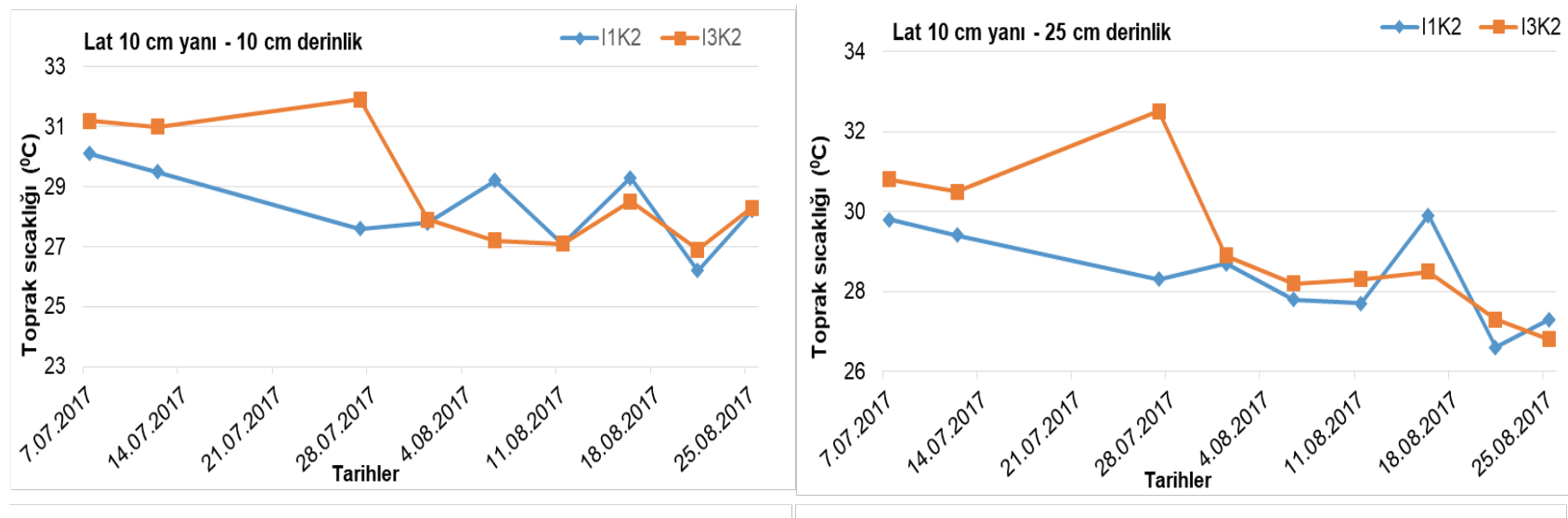

33 Lat $10 \mathrm{~cm}$ yanı- $20 \mathrm{~cm}$ derinlik $\rightarrow-11 \mathrm{~K} 2-13 \mathrm{~K} 2$
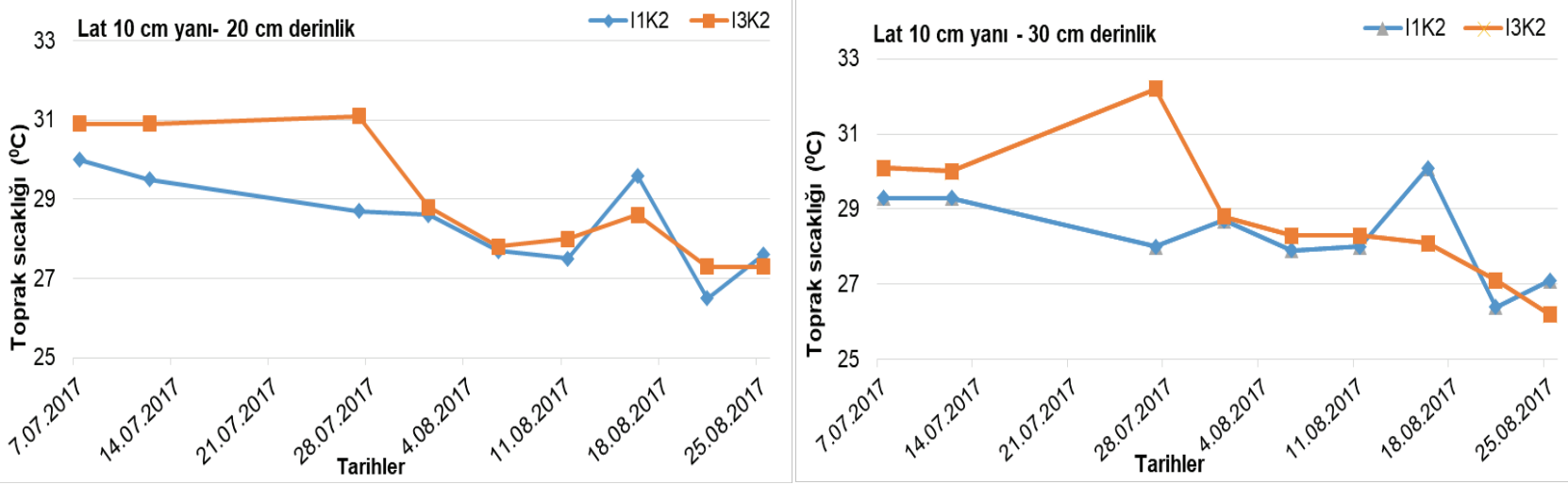

Șekil 2. Yüzey ve yüzeyaltı damla sulama sistemlerinde toprak derinliklerine göre lateralin 10 uzağında toprak sıcaklık değișimi (2017) Figure 2. Temperature variation near $10 \mathrm{~cm}$ of the lateral under surface and subsurface drip irrigation systems according to different soil depths (2017) 
göre toprak içi sıcaklığın $0.6^{\circ} \mathrm{C}$ daha düșük olduğu, bu durumun ise verimde, bitki boy ve kök gelișimine olumlu yansıdığı belirtilmiștir (Dong vd., 2016).

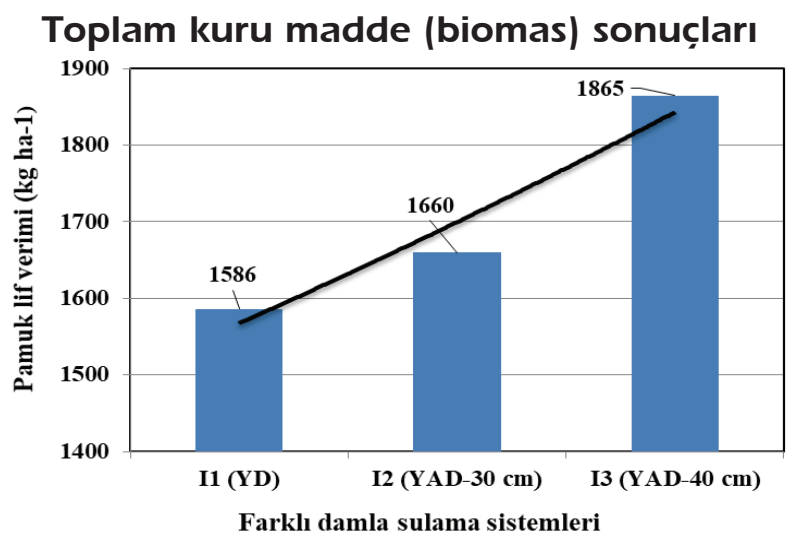

Șekil 3. Farklı damla sulama sistemlerinin pamuk lif verimine etkisi (2 yıllık ortalama)

Figure 3. The effects of differemt drip irrigation systems on cotton lint yield (Average for 2 years)

Deneme yıllarına ve konularına göre elde edilen toprak üstü toplam kuru madde (biomas) miktarları Çizelge 2'de verilmiștir. Elde edilen sonuçlara göre, en yüksek kuru madde (biomas) miktarı her iki deneme yılında da, laterallerin 40 $\mathrm{cm}$ toprak derinliğine yerleștirildiği YAD sulama sistemi ile, FAO-56 PM yöntemine göre tahmin edilen bitki su tüketim değerinin 1.25 katı sulama suyunun uygulandığı konudan $\left(\mathrm{I}_{3} \mathrm{~K}_{1}\right)$ elde edilmiștir. En düșük kuru madde (biomas) miktarı ise benzer șekilde her iki deneme yılında da, YD sulama sistemi ve FAO-56 PM yöntemine göre tahmin edilen bitki su tüketim değerinin 0.75 katı sulama suyunun uygulandığı (en düșük sulama suyu düzeyi) konudan $\left(\mathrm{I}_{1} \mathrm{~K}_{3}\right)$ elde edilmiștir. Buna göre, yüzey damla sulamadan yüzeyaltı damla sulamaya doğru pamuk lif veriminde önemli artıș meydana gelmiștir (Șekil 3, Çizelge 2 ve 3). Benzer artıș sulama suyunun artıșı ile de olmuștur.

Deneme yılları arasında tüm konular bazında, toplam kuru madde (biomas) miktarları 2016 yllında 2017 yılına göre oldukça düșük düzeyde kalmıștır (Çizelge 2). Bunun nedenleri arasında, 2016 yılında daha yüksek sıcaklık ve toprakların yüksek kil içerikleri (\% 65) de gözönüne alındığında, bitkilerin yetersiz çimlenme ve yetișme dönemi bașında nispi olarak daha zayıf olması gösterilebilir.

Yapılan varyans analiz sonuçlarına göre, 2016 yılında uygulanan farklı sulama suyu miktarları kuru madde (biomas) miktarı üzerinde istatistiksel olarak $\% 1$ hata düzeyinde etkili olmuștur. Denemenin ikinci yılı olan 2017 yılında ise, hem farklı damla sulama sistemleri hem de sulama suyu miktarları istatistiksel olarak \% 1 hata düzeyinde ayrı ayrı kuru madde (biomas) üzerinde etkili olmuștur. Bu nedenle deneme yıllarına ait farklı damla sulama sistemi ve farklı sulama suyu miktarlarına karșilık elde edilen kuru madde (biomas) değerleri Çizelge 3'de ayrıca verilmiștir.

Buna göre, farklı damla sulama sistemleri içerisinde en yüksek ortalama kuru madde (biomas) miktarı (7.24 t ha-1) $40 \mathrm{~cm}$ derinliğe yerleștirilen YAD sulama sisteminden elde edilirken, farklı sulama suyu uygulamalarında ise, FAO-56 PM yöntemine göre tahmin edilen bitki su tüketim değerinin 1.25 katının uygulandığı sulama suyu uygulaması en yüksek biomas değerini (8.15 $\left.\mathrm{t} \mathrm{ha}^{-1}\right)$ vermiștir.

Çizelge 2. Pamukta deneme konularına göre toprak üstü aksamın toplam kuru madde miktarı (biomass)(t ha ${ }^{-1}$ )

Table 2. The amounts of total biomass of cotton according to the experimental treatments

\begin{tabular}{|c|c|c|c|c|c|c|c|}
\hline \multirow[b]{2}{*}{ Ana } & \multirow[b]{2}{*}{ Alt } & 2016 & \multicolumn{3}{|c|}{2017} & \multicolumn{2}{|r|}{ Ortalama } \\
\hline & & $\begin{array}{c}\text { Sulama suyu } \\
(\mathrm{mm})\end{array}$ & $\begin{array}{l}\text { Biomas } \\
\left(\mathrm{t} \mathrm{ha}^{-1}\right)\end{array}$ & $\begin{array}{c}\text { Sulama suyu } \\
(\mathrm{mm})\end{array}$ & $\begin{array}{c}\text { Biomas (t } \\
\text { ha-1) }^{-1}\end{array}$ & $\begin{array}{c}\text { Sulama suyu } \\
(\mathrm{mm})\end{array}$ & $\begin{array}{c}\text { toplam biomas } \\
\text { (t ha-1) }\end{array}$ \\
\hline \multirow[t]{3}{*}{11} & $\mathrm{~K}_{1}$ & 606.2 & 4.36 & 675.9 & 10.59 & 641.1 & 7.48 \\
\hline & $\mathrm{K}_{2}$ & 458.1 & 4.44 & 517.6 & 8.97 & 487.9 & 6.71 \\
\hline & $\mathrm{K}_{3}$ & 310.2 & 3.68 & 303.1 & 4.83 & 306.7 & 4.26 \\
\hline \multirow[t]{3}{*}{12} & $\mathrm{~K}_{1}$ & 604.6 & 5.37 & 676.0 & 11.00 & 640.3 & 8.19 \\
\hline & $\mathrm{K}_{2}$ & 540.2 & 5.68 & 522.6 & 7.00 & 531.4 & 6.34 \\
\hline & $\mathrm{K}_{3}$ & 337.8 & 3.08 & 364.1 & 4.50 & 351.0 & 3.79 \\
\hline \multirow[t]{3}{*}{13} & $\mathrm{~K}_{1}$ & 661.5 & 6.00 & 685.8 & 11.58 & 673.7 & 8.79 \\
\hline & $\mathrm{K}_{2}$ & 543.9 & 5.18 & 558.7 & 9.33 & 551.3 & 7.26 \\
\hline & $\mathrm{K}_{3}$ & 363.2 & 4.28 & 375.6 & 7.08 & 369.4 & 5.68 \\
\hline
\end{tabular}


Çizelge 3. Denemedeki ana ve alt konulara göre ayrı ayrı kuru madde (biomas) miktarları (t ha-1).

Table 3. Amount of total biomass according to the main plots and sub-plots

\begin{tabular}{cccccccc}
\hline $\begin{array}{c}\text { Sulama } \\
\text { sistemleri }\end{array}$ & 2016 & 2017 & Ort. & $\begin{array}{c}\text { Farklı sulama suyu } \\
\text { düzeyleri }(\mathrm{mm})\end{array}$ & 2016 & 2017 & Ort. \\
\hline $\mathrm{I}_{1}(\mathrm{YD})$ & $4.16 \mathrm{~b}$ & $8.13 \mathrm{a}$ & 6.12 & $\mathrm{~K} 1(651.7)$ & $5.24 \mathrm{a}$ & $11.06 \mathrm{a}$ & 8.15 \\
$\mathrm{I}_{2}($ YAD-30 cm) & $4.71 \mathrm{ab}$ & $7.50 \mathrm{~b}$ & 6.12 & $\mathrm{~K} 2(523.5)$ & $5.10 \mathrm{a}$ & $8.43 \mathrm{~b}$ & 6.77 \\
$\mathrm{I}_{3}($ YAD-40 cm) & $5.15 \mathrm{a}$ & $9.33 \mathrm{a}$ & 7.24 & $\mathrm{K3}(342.4)$ & $3.68 \mathrm{~b}$ & $5.47 \mathrm{C}$ & 4.58 \\
\hline
\end{tabular}

Ortalama değerler gözönüne alındığında, toprak üstü toplam kuru madde (biomas) değerleri, YAD sulama sisteminde ve sulama suyu miktarının artıșına bağlı olarak artıș göstermiștir (Çizelge 3, Șekil 4). Bu araștırma sonucu elde edilen biomas değerleri gözönüne alındığında, benzer șekilde, Ertek ve Kanber (2001), en yüksek kuru madde (biomas) miktarı, her iki deneme yılında da sulama suyunun en fazla uygulandığı konudan sırasıyla 7.80 ve 6.40 t ha $^{-1}$ olarak tespit etmișlerdir. Bașka bir çalıșmada ise, iyi sulanmıș pamuk, sulanmayan pamuk bitkisine göre kuru madde miktarında \% 39 oranında artıș olduğu bildirilmiștir (Chen vd., 2017). Yapılan bu araștırma sonucu ve belirtilen önceki çalıșma sonuçlarına göre, kuru madde (biomas) miktarını en fazla sulama suyu etkilemekte ve artan sulama suyu kuru madde (biomas) miktarını da artırmaktadır.

Ayrıca denemede yer alan 3 farklı damla sulama sisteminde farklı sulama suyu uygulamalarına göre, sulama suyu kuru madde (biomas) arasında regresyon analizleri yapıımıștır. Analiz sonucunda, sulama suyu ile biomas arasında, YD'de $Y=1.48+$ $0.0097 \times\left(R^{2}=0.94 * *\right), Y A D(30 \mathrm{~cm})^{\prime}$ de $Y=-1.55$
$+0.015 X\left(R^{2}=0.99 * *\right)$, ve $Y A D(40 \mathrm{~cm})^{\prime}$ de ise $Y=1.87+0.01 \times\left(R^{2}=0.98^{* *}\right)$, ile tanımlanan ve istatistiksel olarak \% 1 hata düzeyinde önemli doğrusal ilișki tespit edilmiștir (Șekil 5.).

Öte yandan, Phene and Ruskin (1995)'e göre, toprak içindeki nem dağılım boyutunun büyüklüğü, YAD sulamada (tam küresel) YD'ya göre (yarı küresel) daha büyüktür. Bașka bir ifade ile, ıslatılan alan büyüdükçe, kök gelișimi için elverișli toprak hacmi de büyümektedir. Böylece su ve besinlerin absorbsiyonu için elverișilik durumu her ne kadar yıkanma potansiyeli olsa da, YAD sulamada önemli düzeyde artmaktadır.

YAD sulamada, ıslatılan hacmin çoğu daha derinlerde meydana gelir, böylece kök sistemi genellikle yüzey damladan daha düșük sıcaklıkta ve sabit bir çevrenin fonksiyonudur. YAD sulamada toprak yüzeyi kuru kalır, böylece üst topraktan olan buharlașma inmal edilebilir durumdadir (Kalfountzos vd., 2007). Ancak bu durum bu denemede olduğu gibi, toprak bünyesi ve lateral derinliğine bağlı olarak önemli ölçüde değișmektedir. Çünkü, $30 \mathrm{~cm}$ derinlikteki YAD sulamada sulama sonlarına doğru toprak yüzeyinin

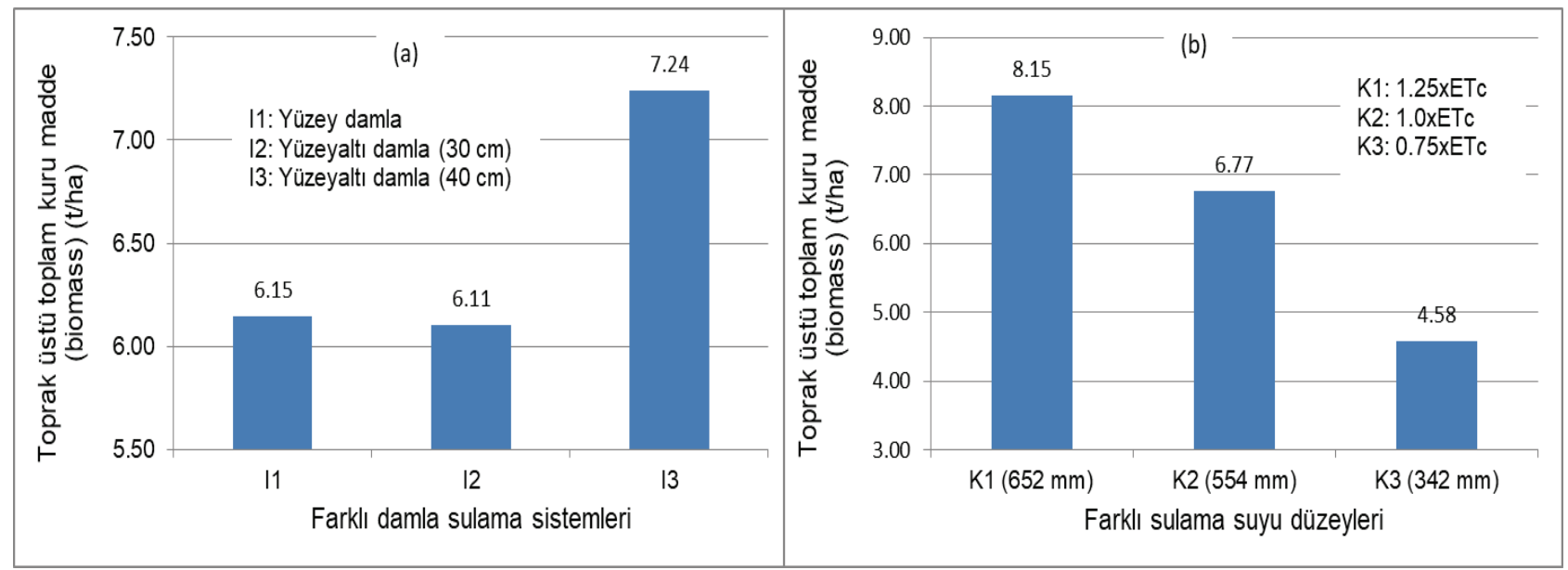

Șekil 4. Pamukta farklı damla sulama sistemleri (a) ve farklı sulama suyu (b) uygulamalarının toprak üstü toplam kuru madde (biomass ) miktarına etkisi

Figure 4. The effect of different drip irrigation systems and different amount of irrigation water on total biomass of cotton 
ıslak hale geldiği görülmüștür. Bu durum lateralin hem $30 \mathrm{~cm}$ derinlikte olması (toprak yüzeyine yakın) hem de toprak bünyesinin \% 65'den fazla kil içermesi nedeniyle kapillariteye bağlanabilir. Aynı durum $40 \mathrm{~cm}$ derinlikte meydan gelmemiștir. Bu ise, $40 \mathrm{~cm}$ derinlikteki yüzeyaltı damlada neden daha yüksek toplam kuru madde (biomas) verimi elde edildiğini de açıklamaktadır. Buna göre YAD sulamada da sistem tasarımı ve ișletilmesi mevcut toprak ve bitki koșulları gözönüne alınarak yapılmasının ne denli önemli olduğunu göstermektedir.

Buna göre, kurak ve yarı kurak bölgelerde pamuk verimi ile toplam kuru madde (biomass) miktarını etkileyen ve/veya belirleyen en önemli faktörün bașında su gelmektedir (Patterson vd., 1978; Çetin ve Bilgel, 2002). Kuru madde (biomas) birikimi ile ilgili olarak, yetișme süresince bitkiler tarafından biriktirilen toplam kuru madde (biomas) fotosentez ve solunum aktivitesinin bir fonksiyonudur (Patterson vd., 1978).

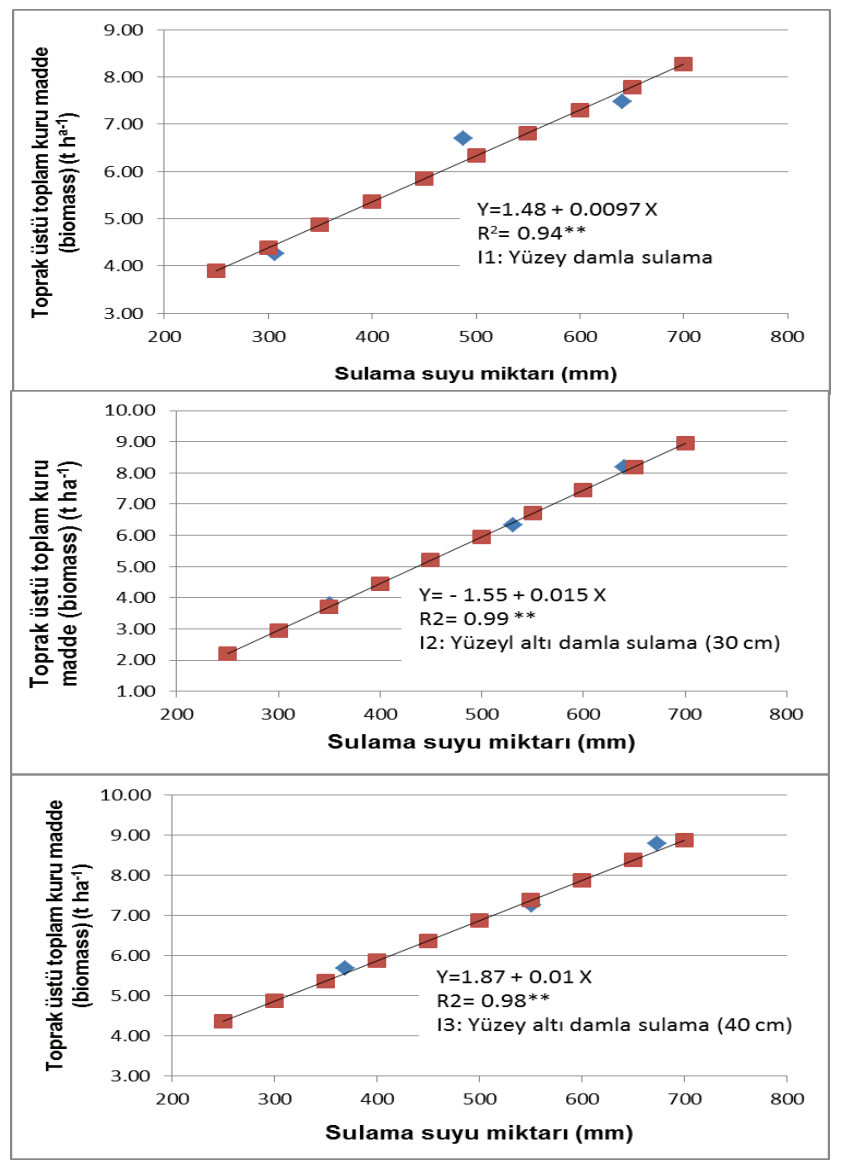

Șekil 5. Farklı damla sulama sistemlerinde, sulama suyu pamuk topraK üstü kuru madde (biomass) ilișkisi

Figure 5. The relationship between different amount of irrigation water and total biomass of cotton on different drip irrigation systems

\section{SONUÇ VE ÖNERILER}

Bu araștırma, pamukta farklı damla sulama sistemlerinde farklı sulama suyu uygulamalarının toprak sıcaklığı ile toplam kuru madde (biomas) verimine etkisi incelemek amaciyla Güneydoğu Anadolu Bölgesi Diyarbakır ilinde, 2016-2017 yıllarında yapılmıștır. Araștırma sonucuna göre, lateralin $10 \mathrm{~cm}$ yakınında farklı derinliklerde yapılan sıcaklık ölçümlerinde, yüzeyaltı damla sulamada yüzey damla sulamaya göre, sulama öncesinde $35 \mathrm{~cm}$ derinlikte $1.47^{\circ} \mathrm{C}, \quad 30 \mathrm{~cm}$ derinlikte $1.53{ }^{\circ} \mathrm{C}, 20 \mathrm{~cm}$ derinlikte $1.25^{\circ} \mathrm{C}$ ve $10 \mathrm{~cm}$ derinlikte ise $0.69^{\circ} \mathrm{C}$ daha yüksek olduğu ölçülmüștür.

Yüzeyaltı damla sulamada yüzey toprağı kuru olduğundan, topraktan olan buharlașma çok sınırlı veya inmal edilebilir düzeyde olduğu gözönüne alınabilir. Bu durum sistem tasarımı ve sulama yönetimi ile yakından ilgilidir. Bu denemede olduğu gibi, çoğu zaman 30 cm derinliğe yerleștirilen yüzeyaltı damla sulama uygulamasında, toprak yüzeyinin ıslak olduğu görülmüștür. Bu durumun kapillarite ile suyun toprak yüzeyine kadar çıktığı böylece buharlașma kayıplarının $40 \mathrm{~cm}$ derinlikteki yüzeyaltı damla sulamaya göre nispi olarak daha yüksek olduğu söylenebilir. Halbuki, $40 \mathrm{~cm}$ derinliğe yerleștirilen yüzeyaltı damla sulamada ise bu durum genellikle meydana gelmemiș olup, dolayısıyla buharlașma kayıpları da pek olmamıștır. Bu durum, toplam kuru maddenin neden $40 \mathrm{~cm}$ derinlikteki yüzeyaltı damla sulama en yüksek olduğunu da açıklamaktadır. Buna göre, $40 \mathrm{~cm}$ derinlikteki YAD sulamada sulama suyunun, YD ve diğer 30 $\mathrm{cm}$ derinlikteki YAD sulamaya göre daha etkin kullanıldığını göstermektedir.

Öte yandan, kuru madde (biomas) miktarını en fazla sulama suyu etkilemekte ve artan sulama suyu kuru madde (biomas) miktarını da artırmaktadır. Buna göre, farklı damla sulama sistemleri içerisinde en yüksek ortalama kuru madde (biomas) miktarı (8.79 ha-1) $40 \mathrm{~cm}$ derinliğe yerleștirilen YAD sulama sisteminde ve FAO-56 PM yöntemine göre tahmin edilen bitki su tüketim değerinin 1.25 katının uygulandığı sulama suyu uygulamasından elde edilmiștir. Ancak, optimum koșullar (su tasarrufu ve en yüksek su verimliliği) göz önüne alındığında, $40 \mathrm{~cm}$ derinlikteki YAD sulama ile günlük gerçek su tüketimi kadar sulama suyunun uygulandığı (I=1.00xETc) uygulama önerilmiștir. 


\section{TEȘEKKÜR}

Bu makaledeyer alan veriler, TÜBITAK 1150600 No'lu araștırma projesi Sonuç Raporu'nun bir bölümünden elde edilmiștir. Bu nedenle, bu makalenin "Materyal ve Yöntem" bölümünün bir kısmı, ilgili proje verilerinden üretilen farklı makale veya yayın(lar)'ın yalnız "Materyal ve Yöntem" bölümlerinin yalnız bir kısmı ile benzerlik göstermektedir. Belirtilen projenin finansal desteğinin (bütçesi) tamamı TÜBiTAK tarafından sağlanmıștır. Bu nedenle kurumsal olarak TÜBITAK'a teșekkür ederim. Arazi çalıșmalarında katkı sunan Doç. Dr. Neșe Üzen, Hilal Altunten ve Bayram Önen'e teșekkür ederim.

\section{KAYNAKLAR}

Adams WR, Zeleke KT (2016). Diurnal effects of on efficiency of drip irrigation. Irrigation Sceince 35: 141-157, Doi: 10.1007/s00271-016-0529-1.

Ali IA, Kafkafi U, Yamaguchi I, Sugimoto $Y$, Inanaga $S$ (1996). Transpiration drop after sudden decrease in root temperature. International Evapotranspiration and Irrigation Scheduling Conference. San Antonio, Texas, USA, November 3-6, 1996.

Allen RG, Pereira LS, Raes D, Smith M (1998). Crop evapotranspiration: Guidelines for computing crop water requirements". United Nations Food and Agriculture Organization, Irrigation and Drainage Paper 56, Rome.

Anonim (2016). Bitkisel üretim istatistikleri. Türkiye İstatistik Kurumu, www.tuik.gov.tr, Erișim tarihi: 15.06.2016.

Bronson KF, Chua TT, Booker JD, Keeling JW, Lascano R (2003). In-season nitrogen status sensing in irrigated cotton: II. Leaf nitrogen and biomass. Soil Sci. Soc. Am. J. 67:14391448. Chen Z, Ma H, Xia J, Hou F, Shi X, Hao X, Hafeez A, Han $H$, Luo H (2017). Optimal pre-plant irrigation and fertilization can improve biomass accumulation by maintaining the root and leaf productive capacity of cotton crop. Scientific Reports, Volume 7, Article number: 17168, doi:10.1038/s41598-01717428-5.

Colaizzi PD, Evett SR, Howell TA (2004). Comparison of SDI, LEPA and spray irrigation performance for cotton in the North Texas High Plains". CD-ROM. Irrigation Association Annual Meeting, 14-16 Nov. Tampa, FL. USA.

Çetin Ö (1993). GAP'ta sulama sistemleri ve su Tasarrufu. ToprakSu Dergisi, 1 : 23-24.

Cetin Ö, Bilgel L (2002). Effects of Different Irrigation Methods on Shedding and Yield of Cotton. Agric. Wate. Manage, Volume 54 (1), 1-15.

Çetin Ö, Üzen N (2016). Pamuk sulaması. Çiftçi ve Köy Dünyası. TZOB Dergisi, Ağustos, 2016, 38-41.

Çetin Ö, Üzen N, Temiz MG, Sessiz A (2013). Güneș enerjisi kullanarak damla sulama ile sulanan pamukta fertigasyonda azotlu gübre yönetimi. Dicle Üni. Bilimsel Araștırmalar Koordinatörlüğü (Proje No: ZF-1 0-166) Desteklenen Araștırma Sonuç Raporu, Diyarbakır.
Dehghanisanij $H$, Kosari $H$ (2011). Evapotranspiration partitioning in surface and subsurafce drip irrigation systems, Evapotranspiration-from measurments to agricultural and environmental applications, G. Gerosa (ed.) ISBN:978-953307-512-9.

Dong X, Xu W, Zhang Y, Leskovar DI (2016). Effects of irrigati, on timing on root zone soil temperature root grpwth and grain yield and chemical composition in corn. Agronomy, 6:34, 1-10, doi:10.3390.

Ertek A, Kanber R (2001). Damla yöntemiyle sulanan pamukta farklı sulama programlarının bitki gelișmesine etkileri. Turk J Agric For 25 (2001) 415-425.

Gardner FP, Pears RB, Mitchel RL (1985). Physiology of crop plants. Iowa State University Press. Iova, USA, 327.

Glinski J, Lipiec J (1990). Soil condition and plant roots. CRC Press Boca Baton Fla.

Harem E (2010). Türkiye'de tescil edilen pamuk çeșitleri. TAGEM, GAP Toprak-Su Kaynakları ve Tarımsal Araștırma Enstitüsü Müdürlüğü, Yayın No: 165, Șanlıurfa.

Kalfountzos D, Alexiou I, Kotsopoulos S, Vyrlas P (2007). Effect of subsurface drip irrigation on cotton plantations. Water Resour Manage 21:1341-1351, DOI 10.1007/ s1 1269-006-9085-4.

Karademir C, Karademir E, Doran I, Altıkat A (2005). Diyarbakır ekolojik koșullarında farkı azot ve fosfor uygulamalarının pamukta verim ve lif teknolojik özelliklerine etkisi. GOÜ Ziraat Fak. Dergisi, 2005, 22(1), 55-61.

Keller J, Bliesner RD (1990). Sprinkle and trickle irrigation. Chapman and Hall, 115 Fifth Avenue, New York, NY 10003.

Li X, Simunek J, Shia H, Yana J, Penga Z, Gong X (2017). Spatial distribution of soil water, soil temperature, and plant roots in a drip-irrigated intercropping field with plastic mulch Europ. J. Agronomy 83: 47-56.

Lv G, Hu W, Kang Y, Liu B, Li L, JO S (2013). Root water uptake model considering soil temperature. Journal of Hydrologic Engineering 18(4): 394-400.

Özer MS (1992). Harran Ovası koșullarında pamuğun fosforlu gübre isteği. Köy Hizmetleri Șanlıurfa Araștırma Enstitüsü Müdürlüğü Yayınları Genel Yayın No: 71, Rapor Seri No: R-47, Șanlıurfa

Özer SM, Dağdeviren I (1986). Harran Ovası koșullarında pamuğun azotlu gübre isteği. Köy Hizmetleri Araștırma Enstitüsü Yayınları, Yayın No:25, Rapor Serisi No: 1 7, Șanlıurfa.

Patterson LL, Buxton DR, Briggs RE (1978). Fruiting in cotton as affected by controlled boll set. Agron. J. 70:118122.

Phene CJ, Ruskin R (1995). Potential of subsurface drip irrigation for management of nitrate in wastewater. In: Lamm FR (ed) Microirrigation for a changing world: conserving resources/preserving the environment. Proceedings of the 5th international microirrigation congress, April 2-6. Orlando, Florida, pp 155-167, American Society of Agricultural Engineers.

Swern D (1982). Bailey's industrial oil and fat products. A Wiley Interscience Publication, Vol. 2, 1-69. USA. 